Original Research Paper

\title{
Flood Vulnerability Mapping to Riverine Floods: A Study on the Old Brahmaputra River
}

\author{
Muhammad Rezaul Rakib, Md. Nurul Islam and Muhammod Nazrul Islam \\ Department of Geography and Environment, Jahangirnagar University, Bangladesh
}

\section{Article history}

Received: 21-07-2017

Revised: 25-09-2017

Accepted: 16-10-2017

Corresponding Author: Muhammad Rezaul Rakib Department of Geography and Environment, Jahangirnagar University, Bangladesh Email: mrrakib@juniv.edu

\begin{abstract}
Flood is an inevitable natural phenomenon occurring from time to time in all rivers and natural drainage systems of Bangladesh. It causes damage to lives and natural resources as well as the loss of economy and health. This study illustrates the flood vulnerability mapping to riverine floods in the Old Brahmaputra River in Mymensingh Sadar upazila. The flood vulnerability mapping of fourteen unions of Mymensingh Sadar is made by using satellite images, a structured questionnaire, observation and secondary data. Flood vulnerability mapping is a necessary pre-requisite for comprehensive flood mitigation programs. This study emphasizes the importance and needs of looking the phenomena of floods and floods vulnerable area at the national scale in order to fully understand and completely deal with the problem. Totally flood vulnerable unions are Borar Char, Paranganj, Sirta, Char Ishwardi and Char Nilakshmia and flood vulnerable free unions are Ghagra, Dapunia and Akua. With these flood vulnerability mapping, the legal authority can take necessary steps to reduce the flood risk.
\end{abstract}

Keywords: Flood, Vulnerability, River, Map, Old Brahmaputra

\section{Introduction}

Flood is the major disaster affecting Bangladesh year after year. It is an inevitable natural phenomenon occurring from time to time in all rivers and natural drainage systems. The heavy monsoon rain, melting ice, aggradations of riverbed and lowland condition are responsible for flood (Adnan, 1991; Khalequzzaman, 1994). The impact of floods has been increased due to a number of factors, with rising sea levels and increased development on a flood plain (Prithvish and Smita, 2007). In 1987, 1988 and 1998 Bangladesh experienced three extreme floods (Qader, 2003). Regular flooding of the major rivers causes enormous hardship and damage to lives and natural resources. Flood brings not only physical disruption but also socio-psychological and economic dislodgment in the affected areas. Flood impacts on the society and people lose agricultural land, settlements and infrastructures, caused damage of millions of taka often in each and every year of the country. A large number of the population becomes rootless by losing agricultural land and settlements (Alexander 1989a; 1989b; Khalequzzaman, 1991a; 1991b; 1992).

Bangladesh is highly vulnerable to floods due to its geographical location at the deltas of the Ganges, Brahmaputra and Meghna rivers. About $92.5 \%$ of the area of three basins lies outside the boundaries of the country. The hydro-meteorological characteristics of the three river basins are unique and they often cause large to extremely large floods in Bangladesh (Qader, 2003). Flood along the Old Brahmaputra frequently occurs during the rainy season (BWDB, 2010). There are some districts in Bangladesh massively affected by flood; Mymensingh district is one of them. The present research is carried out in the Old Brahmaputra River in Mymensingh Sadar upazila. The Old Brahmaputra River in Mymensingh Sadar causes a great damage and destruction which is not a new phenomenon and at present, this problem is becoming more and more serious. Many towns, cultivable lands, irrigation projects and other valuable infrastructures are situated on the bank of this river. The recurrent flood of this river creates numerous problems. So it is important to make a study on the vulnerability mapping of floods in the Old Brahmaputra River.

\section{Concept of Flood Vulnerability}

The concept of vulnerability expresses the multidimensionality of disasters by focusing attention on the totality of relationships in a given social situation which constitute a condition that, in combination with environmental forces, produces a disaster (Bankoff et al., 2004). Vulnerability to natural hazards is an integral factor in understanding the true extent of risk. 
Vulnerability factors can be divided into three main areas physical vulnerability, social vulnerability and economic vulnerability (Geoscience, 2014).

Risk assessment is a qualitative or quantitative evaluation of the environmental and health risk resulting from exposure to a chemical or physical agent. Risk assessment is the identification of danger and estimation of the probability of an occurrence (Enhealth, 2002). The most common method used to define flood risk consists of calculating the hazard, that is, the physical and statistical aspects of the actual flood (for example: Flood return period, the extent and depth of the flood and flow rate) and the level of vulnerability, the exposure of people and things to the flood and the susceptibility of the elements at risk of suffering damage due to flooding (Veleda et al., 2017). This definition has also been adopted by the EU Floods Directive (2007). Hence, it is comprised of three parameters (Martinez-Graña et al., 2013; 2016): Hazard, vulnerability and exposure and is calculated using the following equation:

\section{Risk $=$ Hazard $\times$ Vulnerability $\times$ Exposure}

Flood vulnerability assessment is an assessment of the risk of flooding to the development being proposed and its possible effects on flood risks elsewhere in terms of its effects. It is the assessment of the livelihood of flooding in a particular area so that development needs and mitigation measures can be carefully considered (Jacobs, 2007). So, an assessment that is required where development is likely to have an impact on water courses and land and properties in the immediate vicinity of watercourses that may be liable to flood.

The vulnerability index was calculated using the following parametric thematic maps: Geomorphology, slopes, elevations, distances, water height and inundation range (Martínez-Graña et al., 2016). In the flood vulnerable map, the following areas could be differentiated.

\section{Most Vulnerable Area}

Presents a high probability of flooding represented in red on the map and signifies a highly vulnerable to humans, due to the depth of the water sheet and the area which is always flooded whenever flood occurred in this study area.

\section{Moderate Vulnerable Area}

Presents a medium probability of flooding represented in orange on the map and is susceptible to frequent flooding. However, this area is recurrently flooded area but not affect mostly thus it is the moderate vulnerable area.

\section{Less Vulnerable Area}

Presents a low probability of flooding represented in yellow on the map and corresponds to those land sectors that present extraordinary and infrequent flooding. However, this area is flooded when the catastrophic flood occurred thus turn into vulnerable. In addition to, which area may be inundated but not susceptible to flooding is defined as the flood free area

\section{Aim and Objectives}

The main aim of this study is to mapping the flood vulnerability in the Old Brahmaputra River. In order to come up with a reasonable analysis to the study of the vulnerability mapping of flood following specific objectives is set to be performed:

- Identification and mapping the vulnerable area affected by riverine flood; and

- Providing planning strategy for the proper development of the study area to reduce the quantity and quality of vulnerability of floods

\section{Data Source and Methodology}

This study is based on primary and secondary data. For the empirical analysis of flood vulnerability mapping, primary data has been collected from the field by formal questionnaire survey and GPS survey. GPS survey provides the absolute and relative location of the vulnerable houses and different physical and cultural features in the global context. For verifying the data informal interview and observation has also done. Different maps, satellite images and database from the BBS, SPARRSO, FFWC, BWDB and BDMB are the sources of static data for this research. With this database, a specific methodology has been followed to produce this research work meaningfully. This study has planned to carry out mainly on the basis of the techniques of Remote Sensing and GIS. Collected data were processed through various levels and had to be compiled at some time. Processing and analyzing the satellite images have been carried out. Data have been analyzed in GIS to visualize the vulnerable zone of floods. Different types of the map produced by using Arc View GIS software with the help of the Land Sat Thematic Mapping Image. Therefore for the fruitful completion of the research work hydrological and some geographical approaches have been analyzed.

\section{Study Area}

Mymensingh Sadar upazila of Mymensingh district is selected as study area for the purpose of the study. The absolute location of study area is between $24^{\circ} 42^{\prime} \mathrm{N}$ and $24^{\circ} 55^{\prime} \mathrm{N}$ latitudes and between $90^{\circ} 13^{\prime} \mathrm{E}$ and $90^{\circ} 28^{\prime} \mathrm{E}$ longitudes with an area of 388.45 square kilometers (Fig. 1). This upazila consists of 1 municipality, 14 union parishads, 136 mouzas and 173 villages and total population is 566368 (Banglapedia, 2014). The Old Brahmaputra, the Sutia and the Negeshwariaremain rivers. The Old Brahmaputra River originates from the left bank of the Brahmaputra to the north of Bahadurabad. Flowing more or less to the southeast it passes by Jamalpur and Mymensingh towns and falls into the Meghna at Bhairab Bazar (Banglapedia, 2014). 


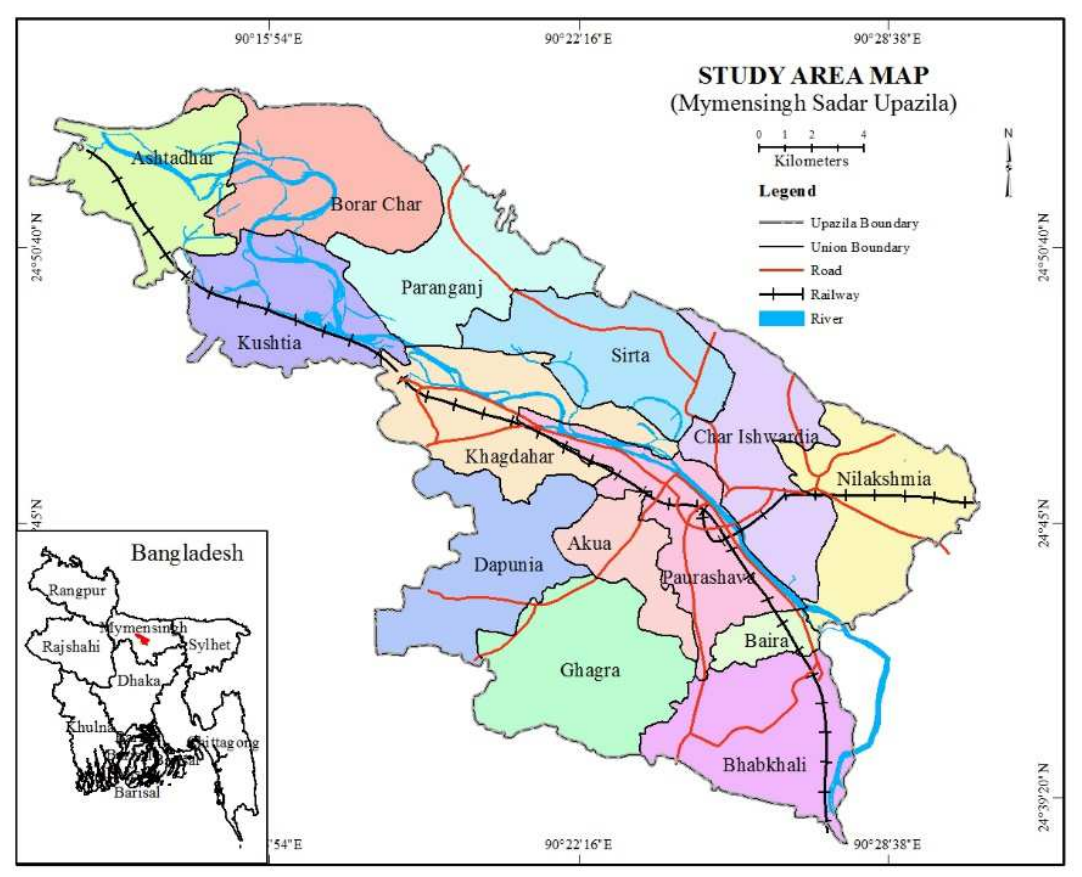

Fig. 1: Study area map (Mymensingh Sadar Upazila) Source: BCA, complied by Author, 2017

\section{Results and Discussion}

The flood vulnerability mapping is a necessary prerequisite for comprehensive flood mitigation programs. Flood zoning concept provides a basis for delineating the flood risk areas. Flood zoning as a concept, however, refers to land relative to its vulnerability to flooding and damage to life and property, recognizing geomorphic units as a basis for flood zoning (Hoyer, 1974). The sequential LANDSAT imageries of Mymensingh Sadar upazila in 1998 and 2007 are compared and mapped to identify the vulnerable zone by flood in the study area. To flood mitigation, it needs to identify the accurately vulnerable area and provide flood hazard information in the form of maps.

\section{Flood Vulnerability Mapping}

Sadar Upazila of Mymensingh district has been subjected to severely affect by the riverine floods. Flood continued along the 37 kilometers long both banks the Old Brahmaputra River under this upazila. The 1998 flood in the Old Brahmaputra River threatened the health and lives of millions through food shortages, the loss of purchasing power for basic necessities and the potential spread of water-borne disease. Poor households did suffering substantial hardship during and after the flood.

The 1998 and 2007 severe floods proved that floods and damages are not decreasing. The flood damage potential is increasing due to the possible causes. High magnitude floods strike on a regular basis in the river basins in Bangladesh. The frequently occurring floods are very costly in terms of human life and economic loss. Therefore, the ability to estimate damages associated with the flood events is very important and is necessary for the evaluation of future alternate flood control policies. Generally, the 1998 and 2007 severe floods are focused in this study. Flood vulnerable maps have developed using the 1998 and 2007 flood images and elevation data (Fig. 2). Flood hazard maps for each simulation hour are created and integrated based on the worst case of hazard level at each Mouza. Flood hazard can be expressed by various combinations of flood characteristics, for instance, flood depth and flood velocity based on research by Ramsbottom et al. (2003).

To identify and analyses the more flood vulnerable area, flood vulnerable mapping is needed with the help of elevation value. In general, the elevation data is derived from various forms, for instance, points, lines and polygons and these data are then aggregated into ground terrain and man-made features. This updated information is used in the Old Brahamputra river of Mymensingh Sadar upazila. Flood vulnerability has categories into three types such as: Most vulnerable area, moderate vulnerable area and less vulnerable area. The left side of the river is more vulnerable for its low elevation than the right side of the river (Fig. 3).

Mymensingh Sadar upazila is widely affected by flood in 1998 and 2007 (Fig. 4, 5 and 6). It is seen that in this area most of the area is affected. Few part of the study area is not flooded (Fig. 7). Over all, it can say that the flood of 1998 is more acute than 2007 because most of the union is affected by the flood to a large extent in 1998. 


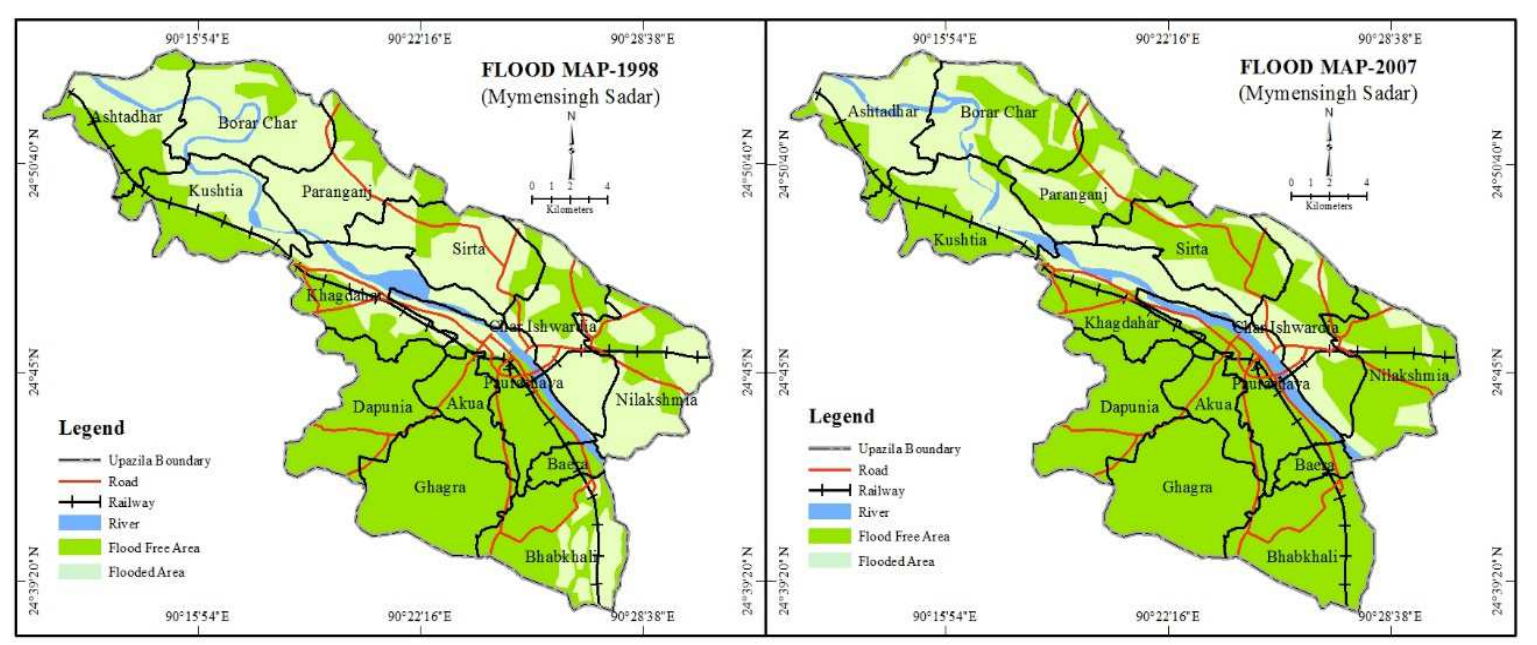

Fig. 2: Flood map in Mymensingh Sadar upazila Source: SPARRSO, 2007

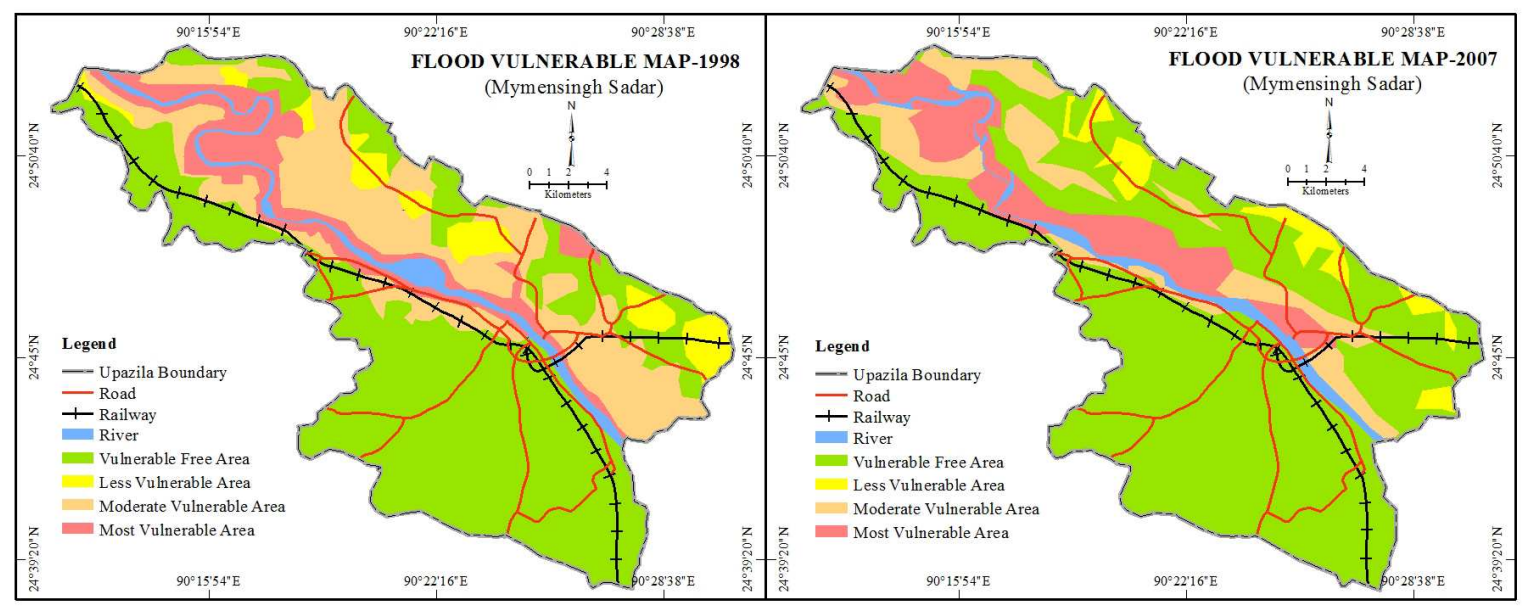

Fig. 3: Flood vulnerable map in Mymensingh Sadar upazila Source: BCA \& LGED, analysis by Author, 2017

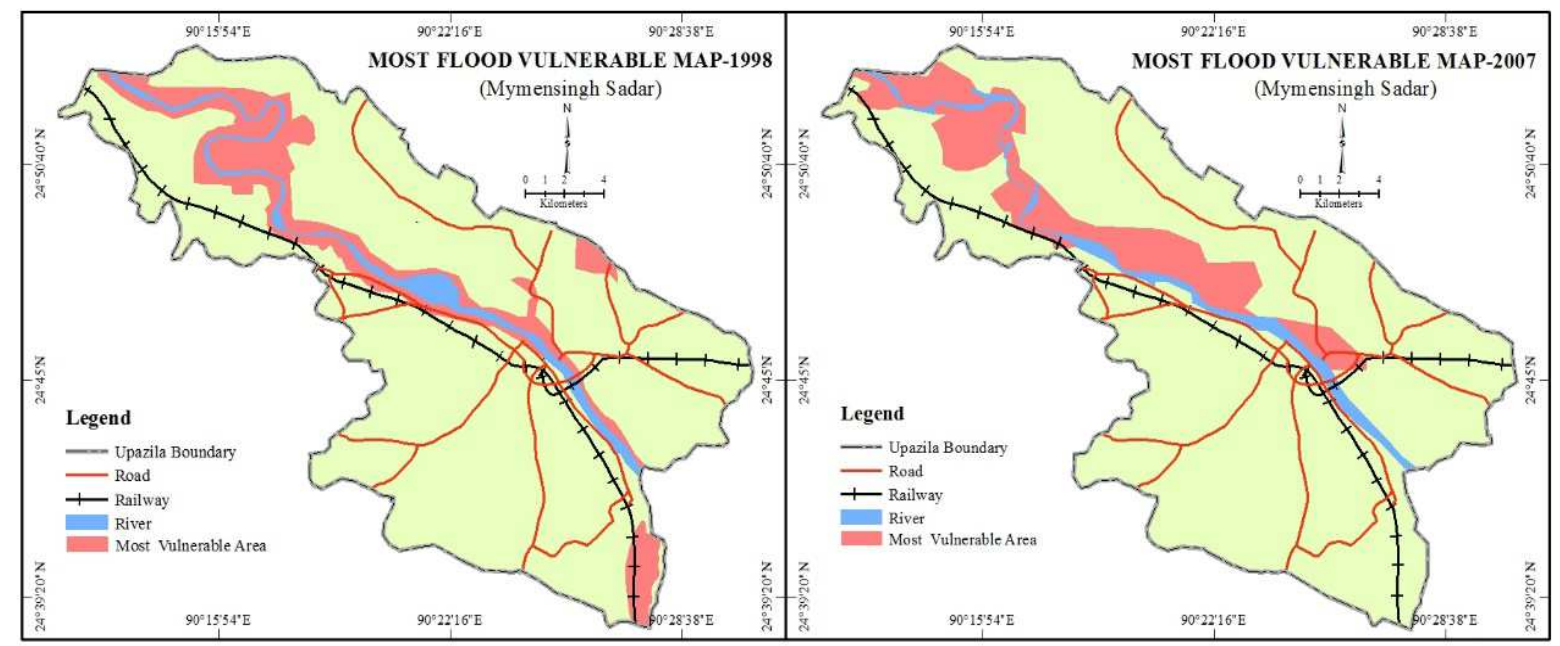

Fig. 4: Most flood vulnerable area in 1998 and 2007 Source: BCA\& LGED, analysis by Author, 2017 


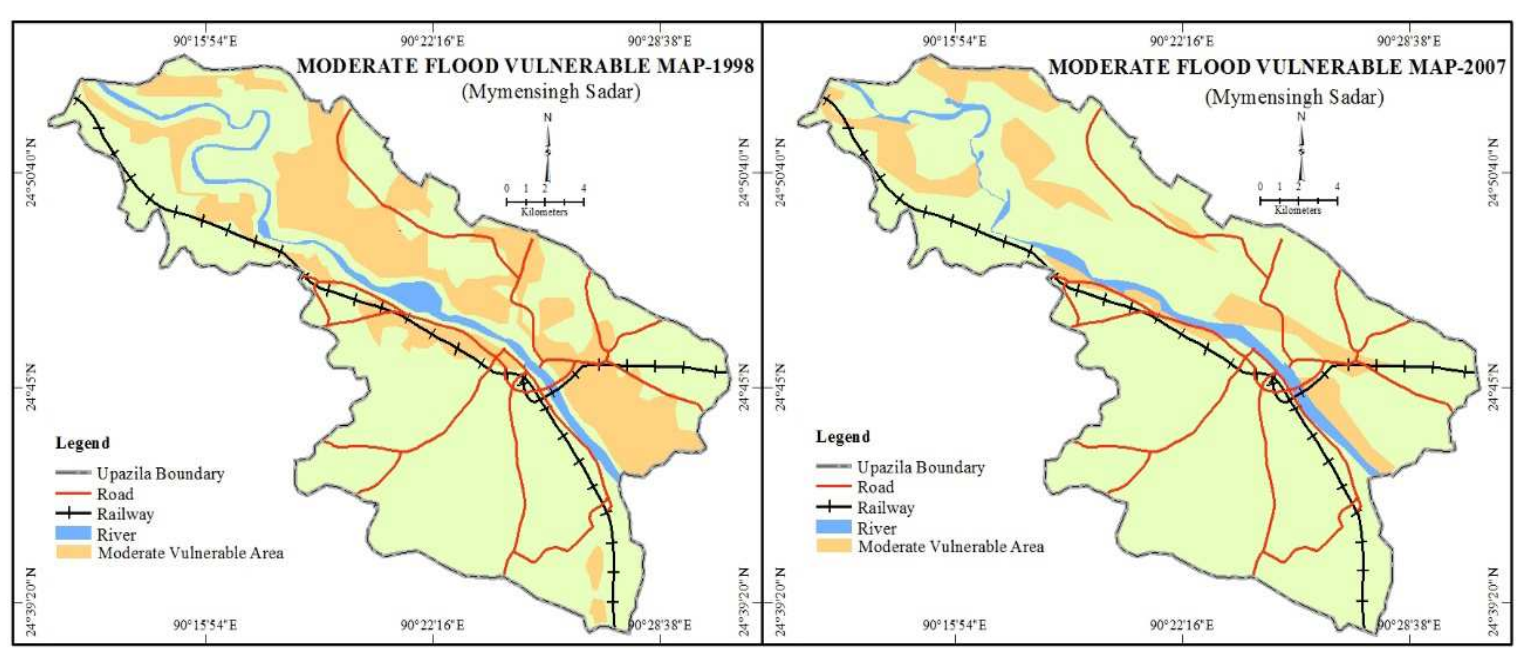

Fig. 5: Moderately flood vulnerable area in 1998 and 2007 Source: BCA\& LGED, analysis by Author, 2017

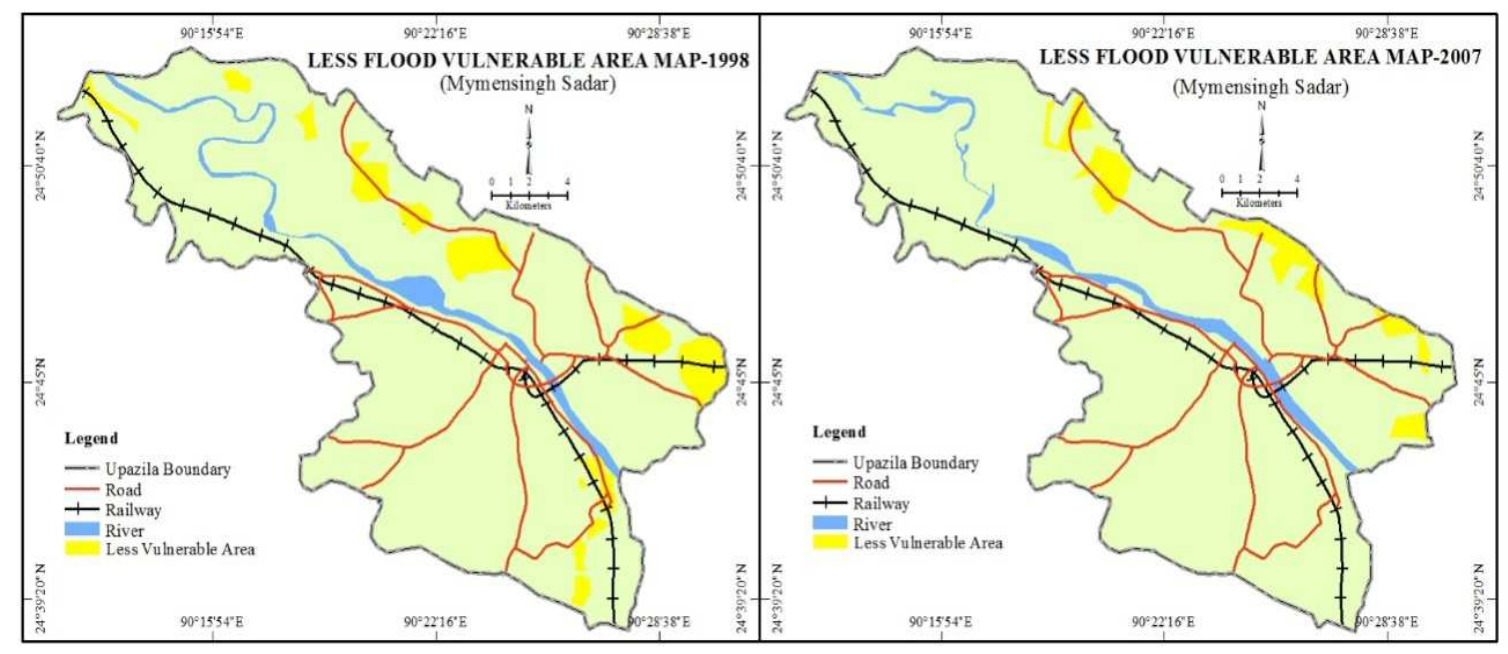

Fig. 6: Less flood vulnerable map in 1998 and 2007 Source: BCA \& LGED, analysis by Author, 2017

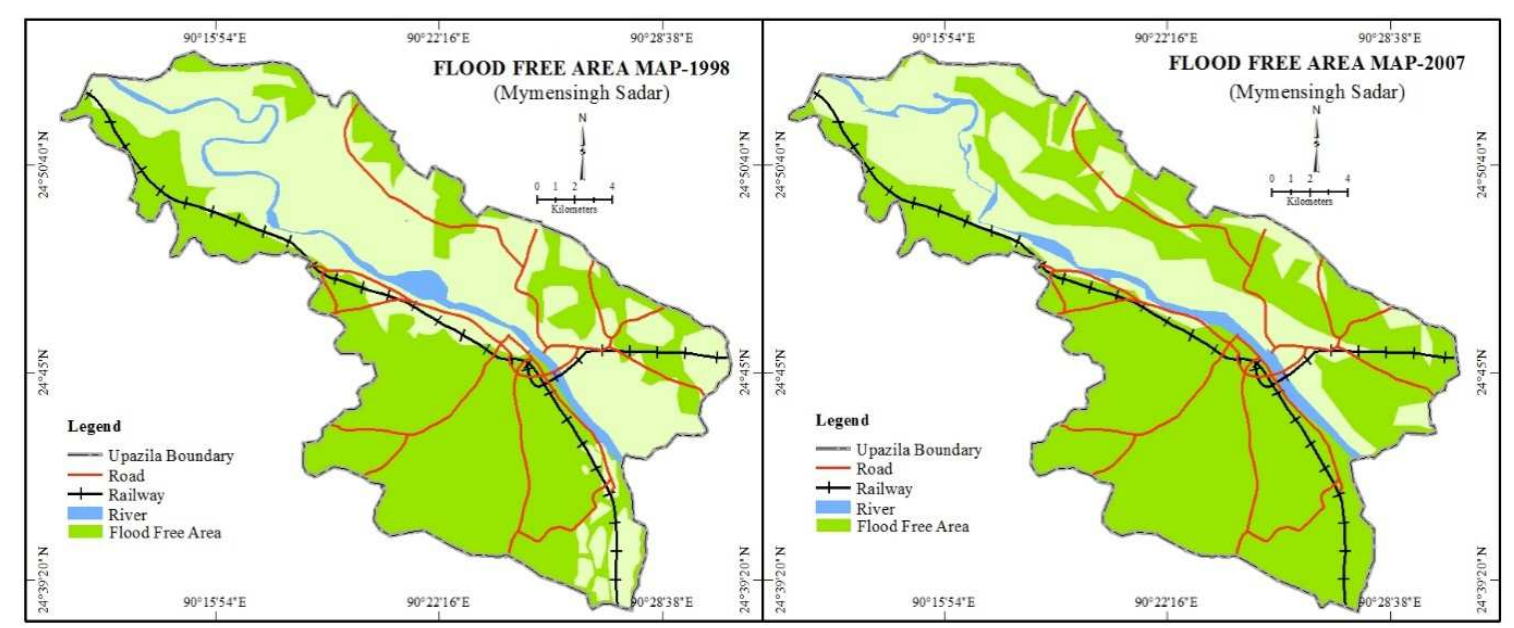

Fig. 7: Flood vulnerable free area map in 1998 and 2007 Source: BCA\& LGED, analysis by Author, 2017 


\section{Flood Vulnerability Mapping According to Union}

Flood has a great impact on Mymensingh Sadar upazila. It caused damages and destructions which have no bounds. Most of the study area is affected by floods. The amount of inundation is highest in 1998 flood rather than 2007 flood. The 1998 flood is more devastating because most of the unions are affected by the flood to a large extent in 1998 (Table 1). There are fourteen unions in this study area. Among them, all unions are not flooded equally. Some unions face more vulnerability, some faces most vulnerability, some unions faces less vulnerability and some unions remain free from flood. All the mouzas of these unions are also not flooded equally. To identify the most vulnerable union or mouza, it is very important to develop flood vulnerability map according to unions. Flood vulnerability map helps to identify the most vulnerable area easily.

From the Fig. 8, it is seen that Ashtadher union of Mymensingh Sadar upazila is affected by the flood. This union is a most vulnerable union in 1998 and 2007 floods. The vulnerability of 1998 flood is greater than the 2007 flood in this union. Most of the mouzas are affected by the flood and some mouzas such as: Bughli, Jaghir Bughli, Kaidapara, Char Sasa, Nimtala which are not affected by the flood. The most vulnerable mouzas are Senerchar, Rehitarapur, Mahismari and Pandapara.

In 1998, Borar Char union is totally affected by the flood. All mouzas are affected by both floods in 1998 and 2007 but this union is most vulnerable in 1998 than 2007 flood which is seen in Fig. 9. Tarapur and Borar Char mouza of Borar Char union are the most vulnerable mouza due to 1998 and 2007 floods.

From the Fig. 10, it is seen that Paranganj union is totally affected by flood in 1998. All the mouzas are affected by flood in both of the years but this union is most vulnerable in 1998 than 2007 because the vulnerability in 1998 is more than 2007 flood. Fewer vulnerability mouzas are Sanadia, Bagadhova, Baola, Abdullahpur, Hiran Palashhia in 2007 flood but Hasadia, Char Shyamrampur and Char Sreekaldi are most vulnerable mouzas. Kushtia union of Mymensingh Sadar upazila is also a vulnerable union in 1998 flood (Fig. 11). This union is affected badly in 1998 and 2007 flood. Char Dari Kushtia, Rupkhali and Terakahada mouzas are most vulnerable mouzas due to both floods. Alipur, Kushtia, Chauania and Putiali mouzas are flood free mouzas in this union.

In 1998 and 2007 floods, Sirta union is affected (Fig. 12). Most of the mouzas are affected in 1998 flood and this union is a most vulnerable union in 1998 flood. The vulnerability of flood is more in Sirta, Para Lakshmipur, Durgapur and Govindapur mouza.

In 1998 and 2007, Khagdahar union is partially affected by flood. But the vulnerability of flood is more in 1998 than 2007 which is seen in Fig. 13. Dulabari, Jelkhanar Char and Kalayanpur mouzas are more vulnerable mouzas due to both floods. But most of the mouzas are flood free mouza in this union such as: Kalikapur, Kalpa, Maijbari, Ghanashyampur, Mirzapur, Bahadurpur and Hasibasi.

Nilakshmia union is one of the most vulnerable unions in 1998 and 2007 floods (Fig. 14). This union is totally affected by the flood and the vulnerability of is so acute in 1998 than 2007. The vulnerability of floods is more in Char Nilakshmia, Phaliamarir Char, Char Durlab and Char Raghurampur. Few mouzas such as Raiganj, Sahabajpur, Rashidpur, Mahazzampur and Modarpur which are not affected in 2007. As a result 1998 flood is the most vulnerable flood in this union.

From the Fig. 15, it is seen that Char Ishwardi union of Mymensingh Sadar upazila is also a vulnerable union in 1998 flood. This union is affected badly in 1998and 2007 flood. Char Ishwardi, Char Haripur, Lakshmipur and Char Barabila mouzasaremore vulnerable mouzas due to both floods and Bajitpur mouza is only a flood free mouza in this union.

Mymensingh Paurashava is totally flood free in 2007. But this Paurashava is flooded in 1998 (Fig. 16). Because there is a dam along the right bank of the Old Brahmaputra river to protect the town from the flood. As a result, this union is moderately vulnerable in 1998.

In 1998, Baera union is flooded and the extent of inundation was more (Fig. 17). This area is totally flood free in 2007. Because this area is in the highland area and it is far from the river comparatively than other unions. For this reason, this union is less vulnerable union. Flood has occurred in Bhabkhali union in 1998 (Fig. 18). But this area is totally flood free in 2007. Because this area is also in the highland area and it is far from the river comparatively than other unions. Few mouzas such as: Dari Bhabkhali, Bhabkhali, Sutiakhali, Narayanpur and Char Amin are most vulnerable mouzas in 1998 flood. As a result 1998 flood is the most vulnerable flood in this union. But this union is the less vulnerable union in 2007 flood.

From the Fig. 19, it reveals that Dapunia, Ghagra and Akua union are totally flooded free in both of the year 1998 and 2007 because these areas are comparatively high and far from the river than the other unions. As a result, this union is not vulnerable in 1998 and 2007 flood. 
Muhammad Rezaul Rakib et al. / Current Research in Geosciences 2017, 7 (2): 47.58 DOI: 10.3844/ajgsp.2017.47.58

Table 1: Union base flood vulnerable area (1998 and 2007)

\begin{tabular}{|c|c|c|c|c|c|}
\hline \multirow[b]{2}{*}{ Union } & \multirow[b]{2}{*}{ Area (sq.km) } & \multicolumn{2}{|l|}{1998} & \multicolumn{2}{|l|}{2007} \\
\hline & & Flooded area (sq.km) & $\%$ & Flooded area(sq.km) & $\%$ \\
\hline Ashtadher & 25.67 & 22.83 & $88.97 \%$ & 18.99 & $74 \%$ \\
\hline Borar Char & 32.07 & 32.07 & $100 \%$ & 29.27 & $89 \%$ \\
\hline Paranganj & 29.77 & 29.77 & $100 \%$ & 10.73 & $37 \%$ \\
\hline Kushtia & 25.58 & 20.75 & $83.43 \%$ & 4.85 & $19 \%$ \\
\hline Sirta & 34.06 & 34.06 & $100 \%$ & 19.38 & $57 \%$ \\
\hline Char Ishwardi & 31.82 & 31.82 & $100 \%$ & 16.54 & $52 \%$ \\
\hline Khagdahar & 33.94 & 20.65 & $60.87 \%$ & 9.84 & $29 \%$ \\
\hline Nilakshmia & 25.85 & 25.85 & $100 \%$ & 6.721 & $26 \%$ \\
\hline Paurashava & 28.36 & 10.23 & $36.08 \%$ & 1.70 & $6 \%$ \\
\hline Dapunia & 27.67 & No & No & No & No \\
\hline Akua & 25.04 & 0.10 & $0.41 \%$ & No & No \\
\hline Ghagra & 25.45 & No & No & No & No \\
\hline Baera & 14.18 & 7.14 & $50.63 \%$ & No & No \\
\hline Bhabkhali & 28.72 & 12.36 & $41.03 \%$ & No & No \\
\hline Total & 388.45 & 247.63 & $63.83 \%$ & 118.02 & $43.22 \%$ \\
\hline
\end{tabular}

Source: Food and Disaster Management Ministry, based on image analysis, 2017

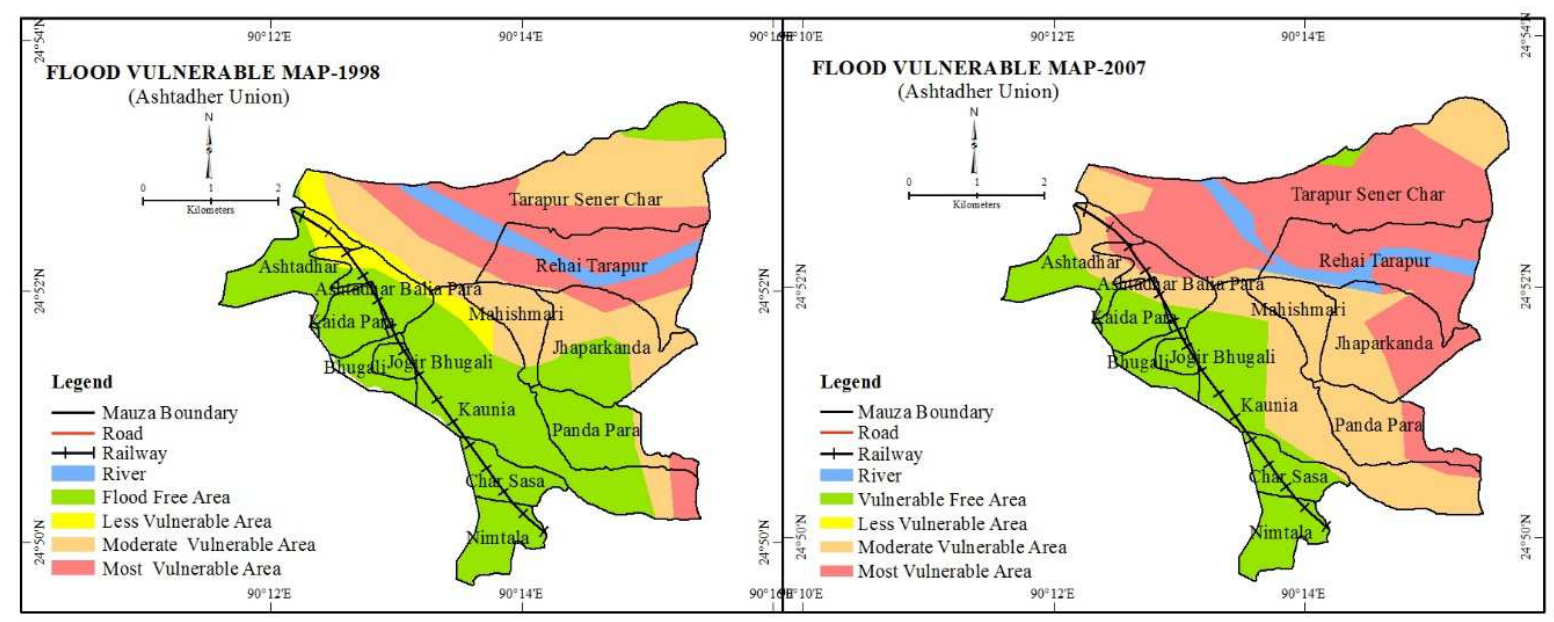

Fig. 8: Mouza base flood vulnerable map of Astadher union, 1998 and 2007 Source: BCA\& LGED, analysis by Author, 2017

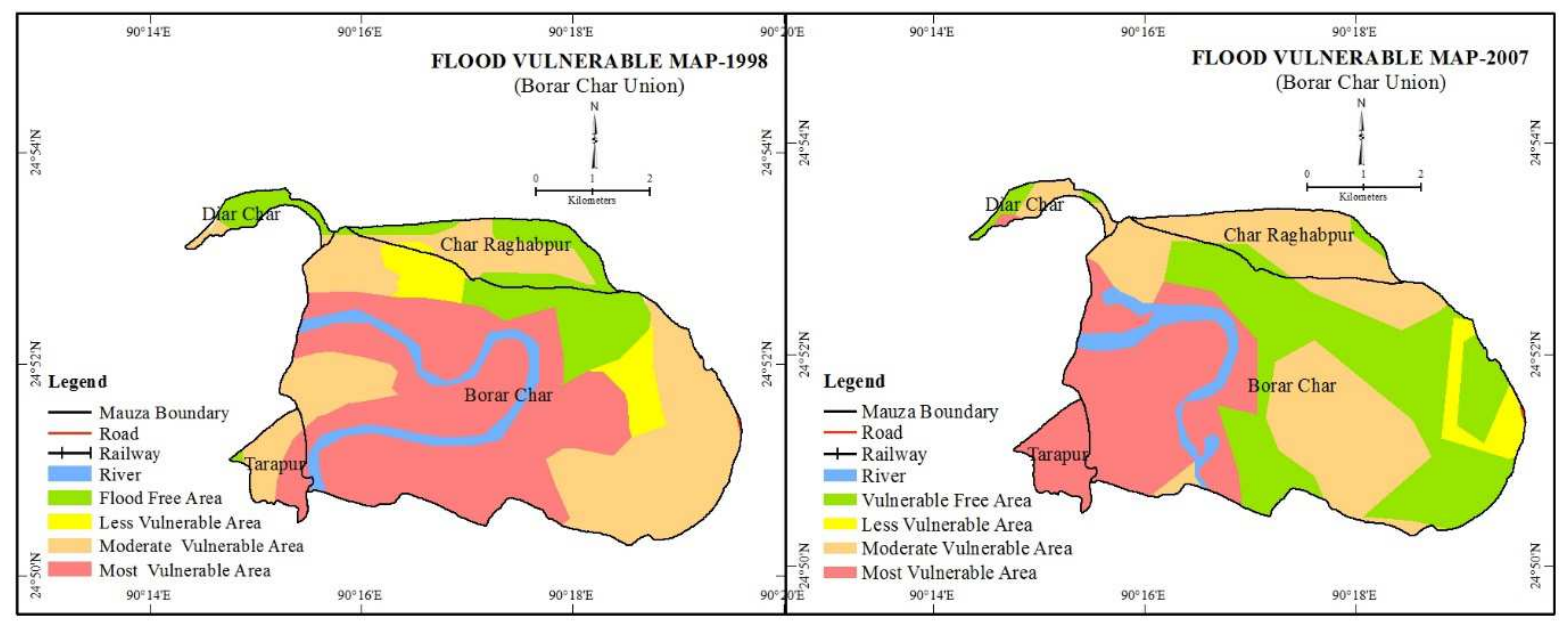

Fig. 9: Mouza base flood vulnerable map of Borar Char union, 1998 and 2007 Source: BCA \& LGED, analysis by Author, 2017 


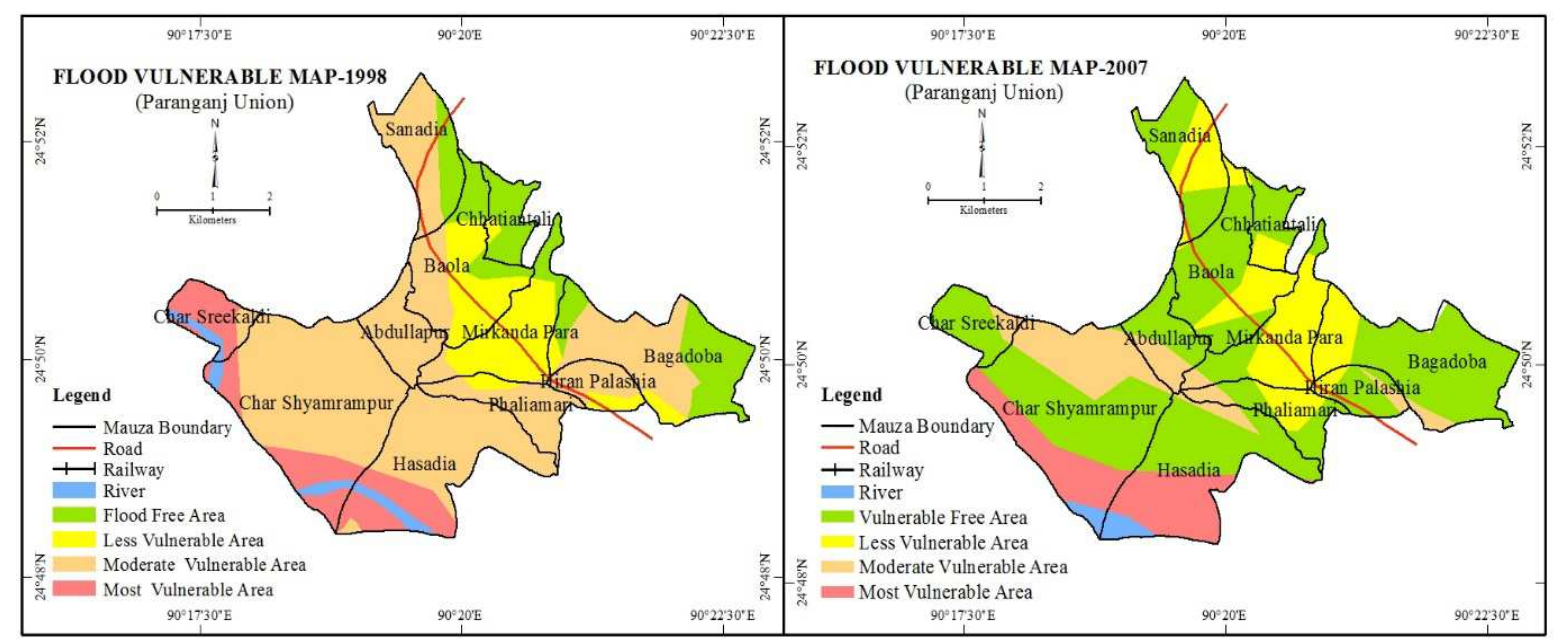

Fig. 10: Mouza base flood vulnerable map of Paranganj union, 1998 and 2007 Source: BCA \& LGED, analysis by Author, 2017

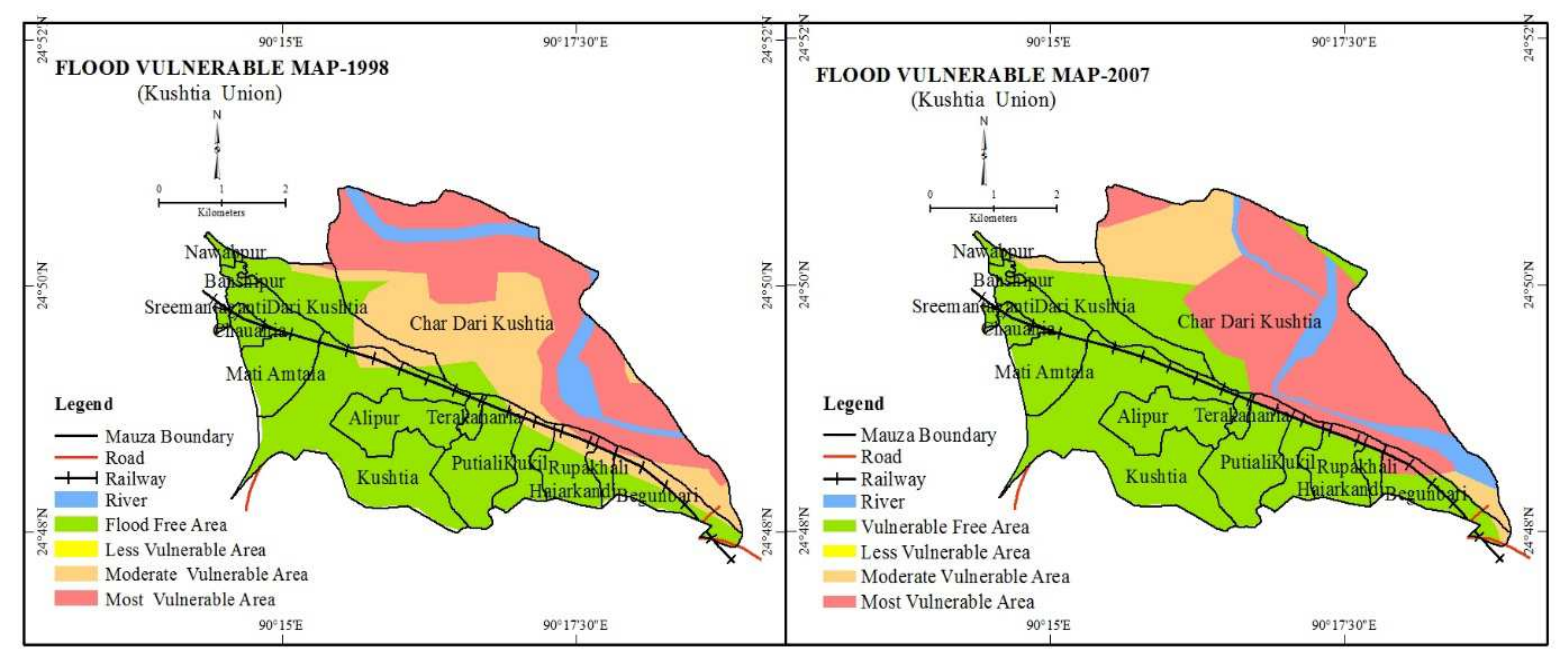

Fig. 11: Mouza base flood vulnerable map of Kushtia union, 1998 and 2007 Source: BCA\& LGED, analysis by Author, 2017

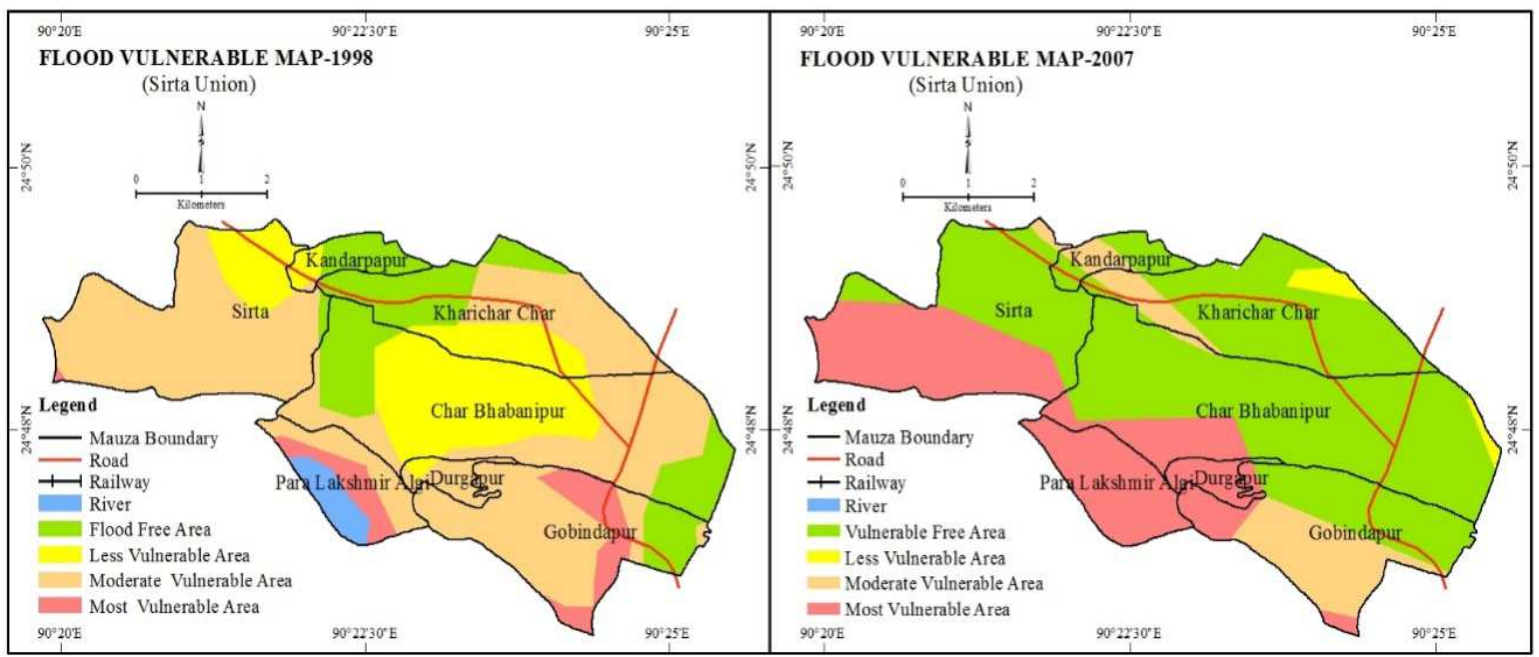

Fig. 12: Mouza base flood vulnerable map of Sirta union, 1998 and 2007 Source: BCA \& LGED, analysis by Author, 2017 


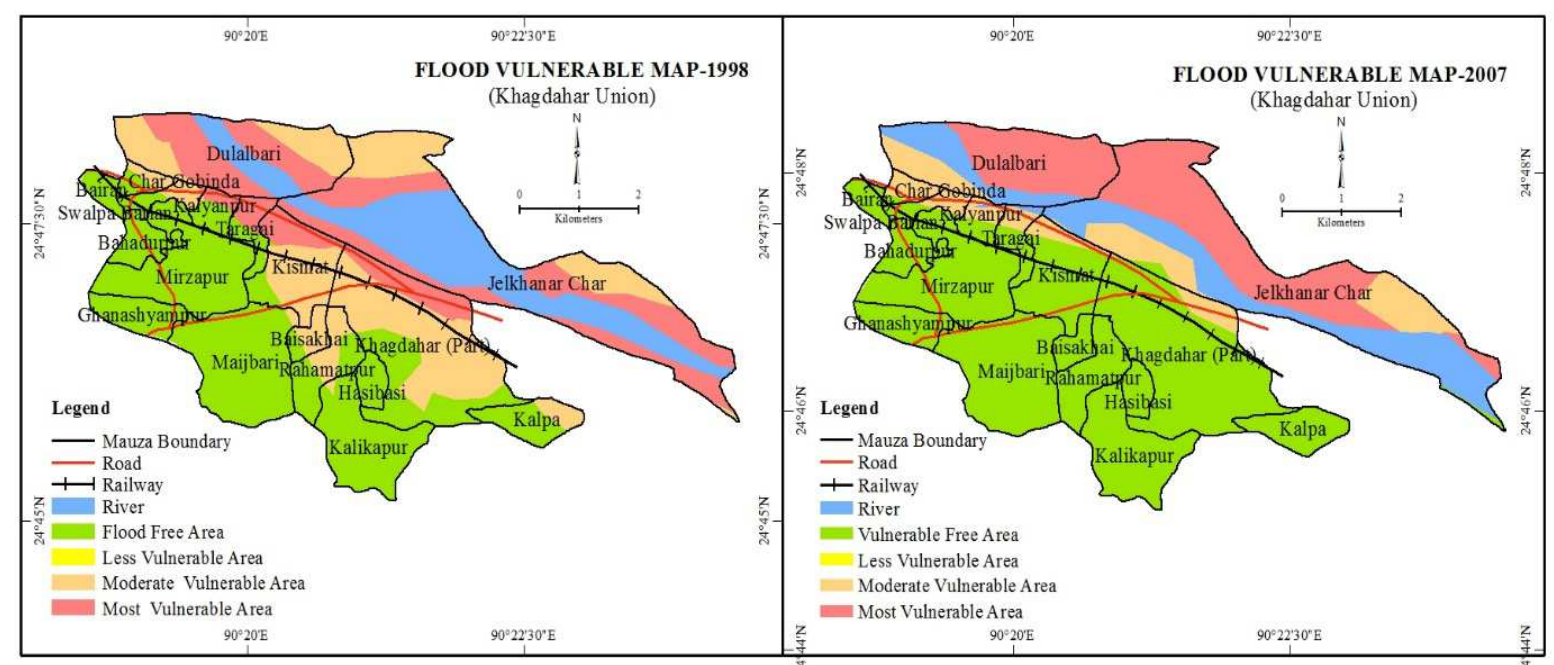

Fig. 13: Mouza base flood vulnerable map of Khagdahar union, 1998 and 2007 Source: BCA \& LGED, analysis by Author, 2017

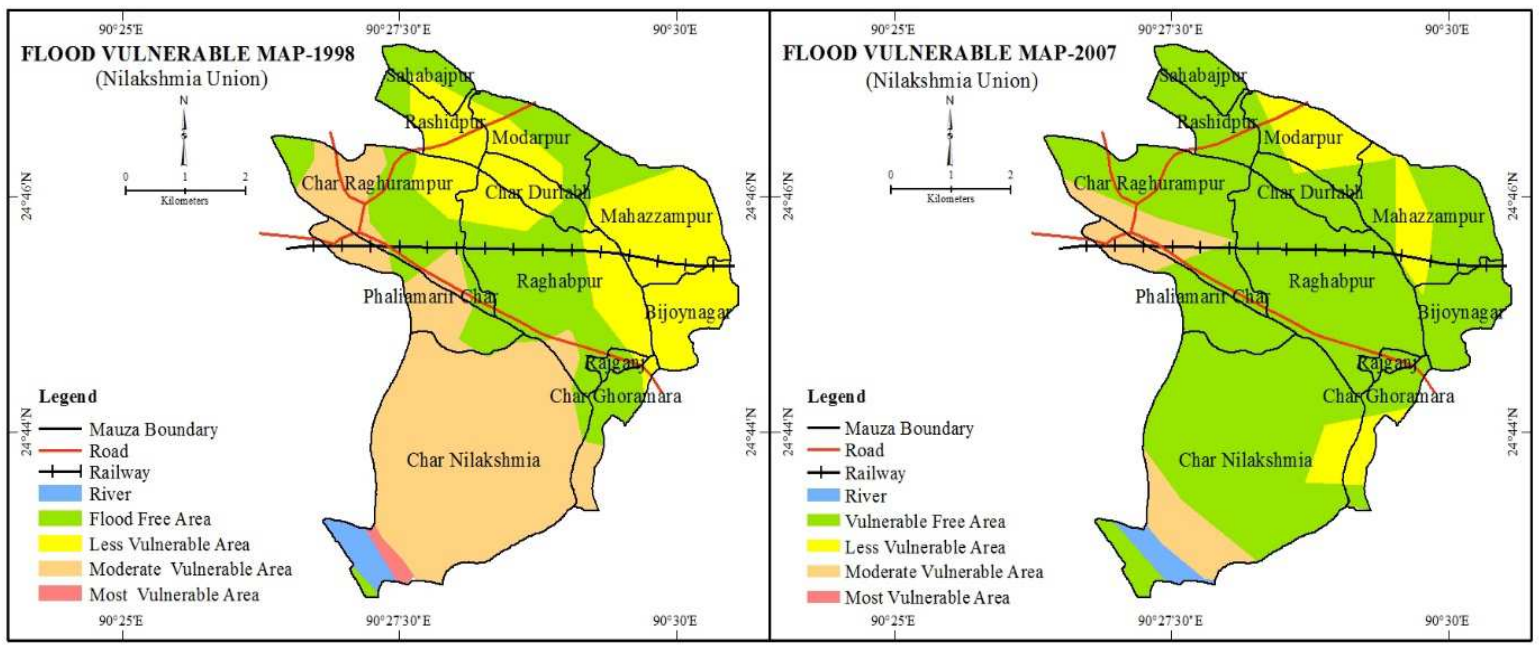

Fig. 14: Mouza base flood vulnerable map of Nilakshmia union, 1998 and 2007 Source: BCA\& LGED, analysis by Author, 2017

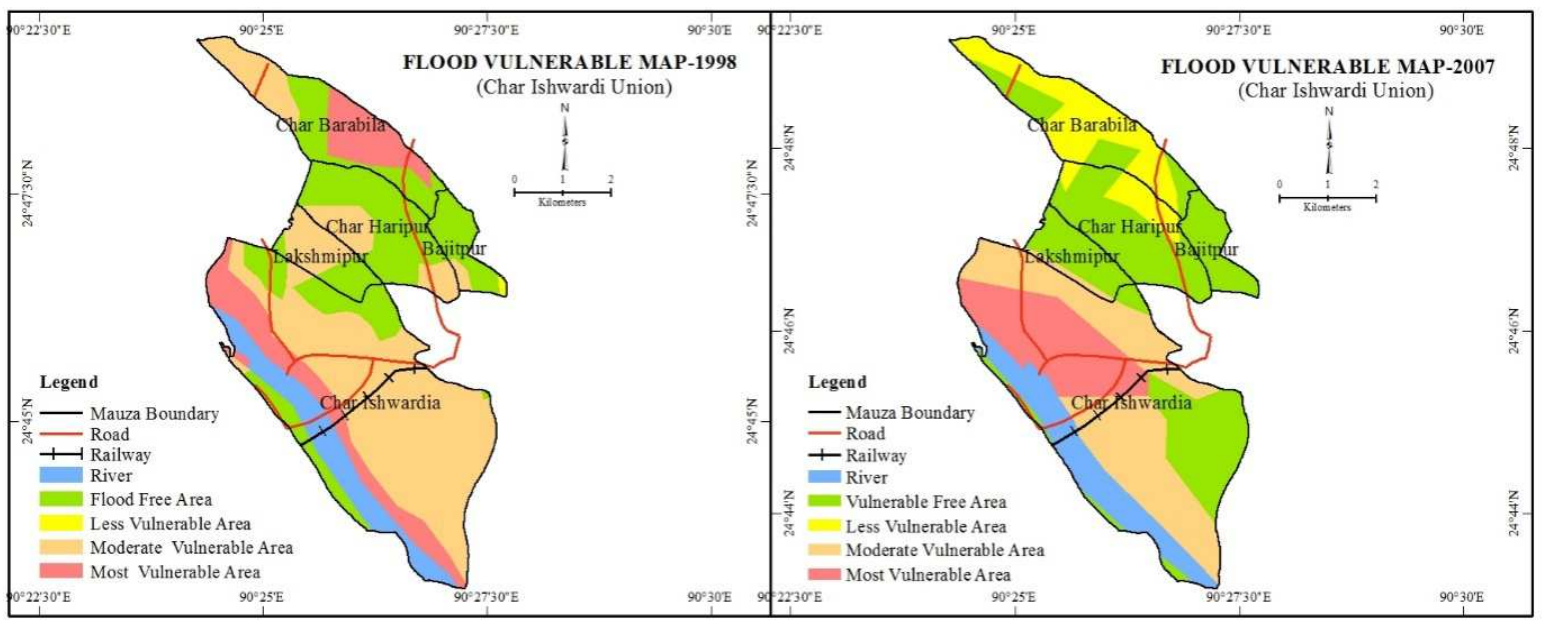

Fig. 15: Mouza base flood vulnerable map of Char Ishwardi union, 1998 and 2007 Source: BCA\& LGED, analysis by Author, 2017 


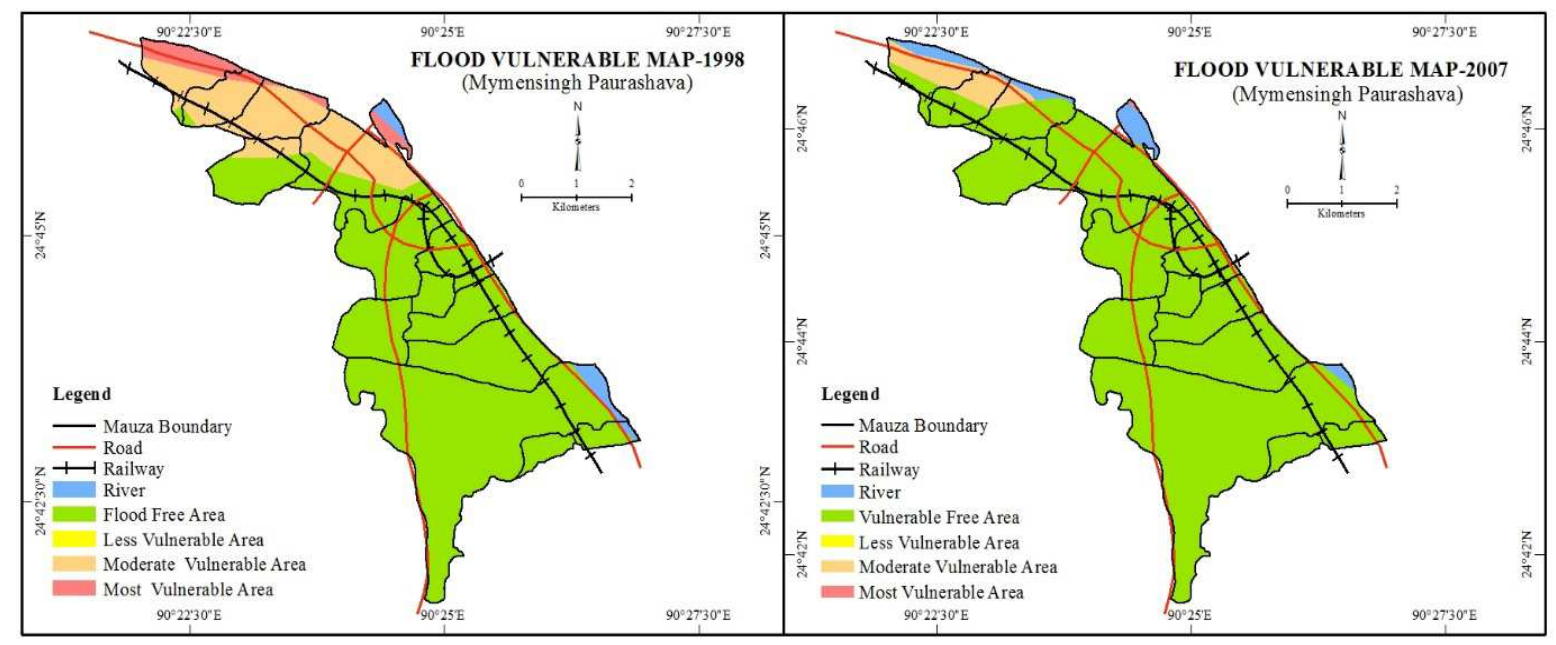

Fig. 16: Mouza base flood vulnerable map of Paurashava, 1998 and 2007 Source: BCA \& LGED, analysis by Author, 2017

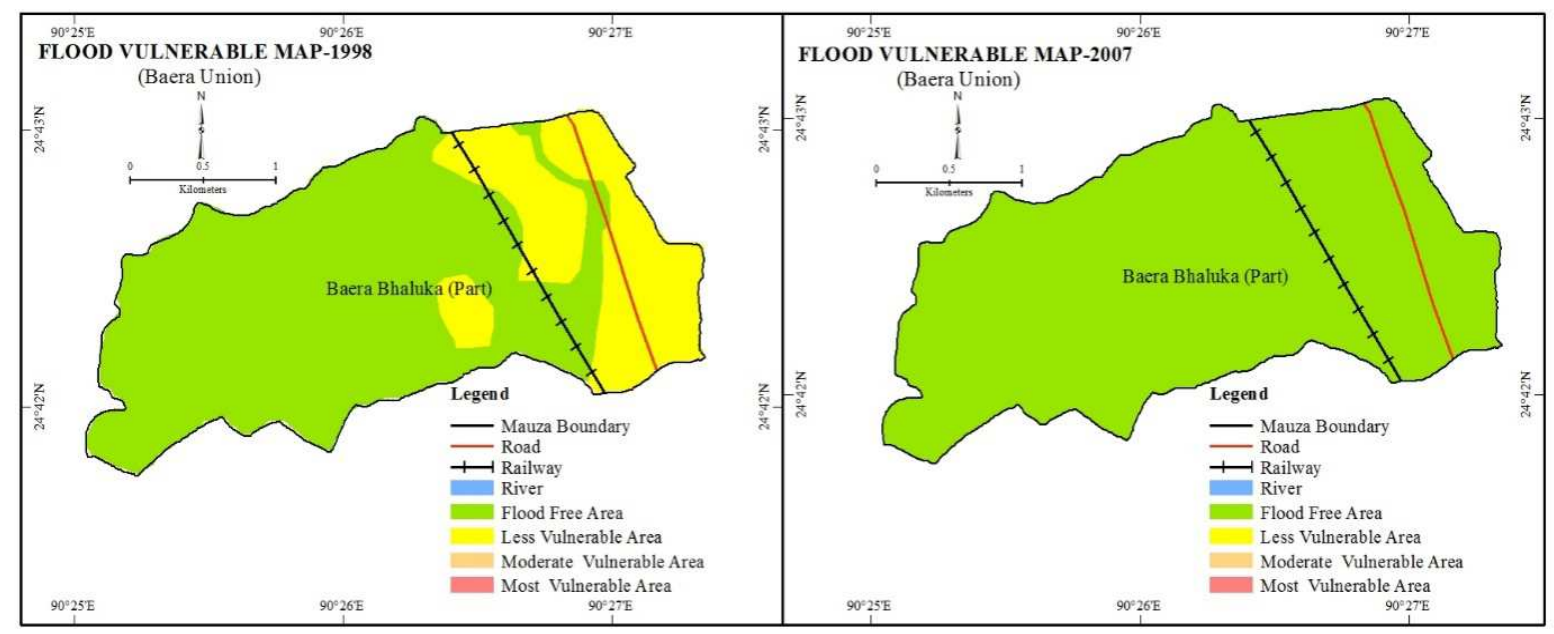

Fig. 17: Mouza base flood vulnerable map of Baera union, 1998 and 2007 Source: BCA\& LGED, analysis by Author, 2017

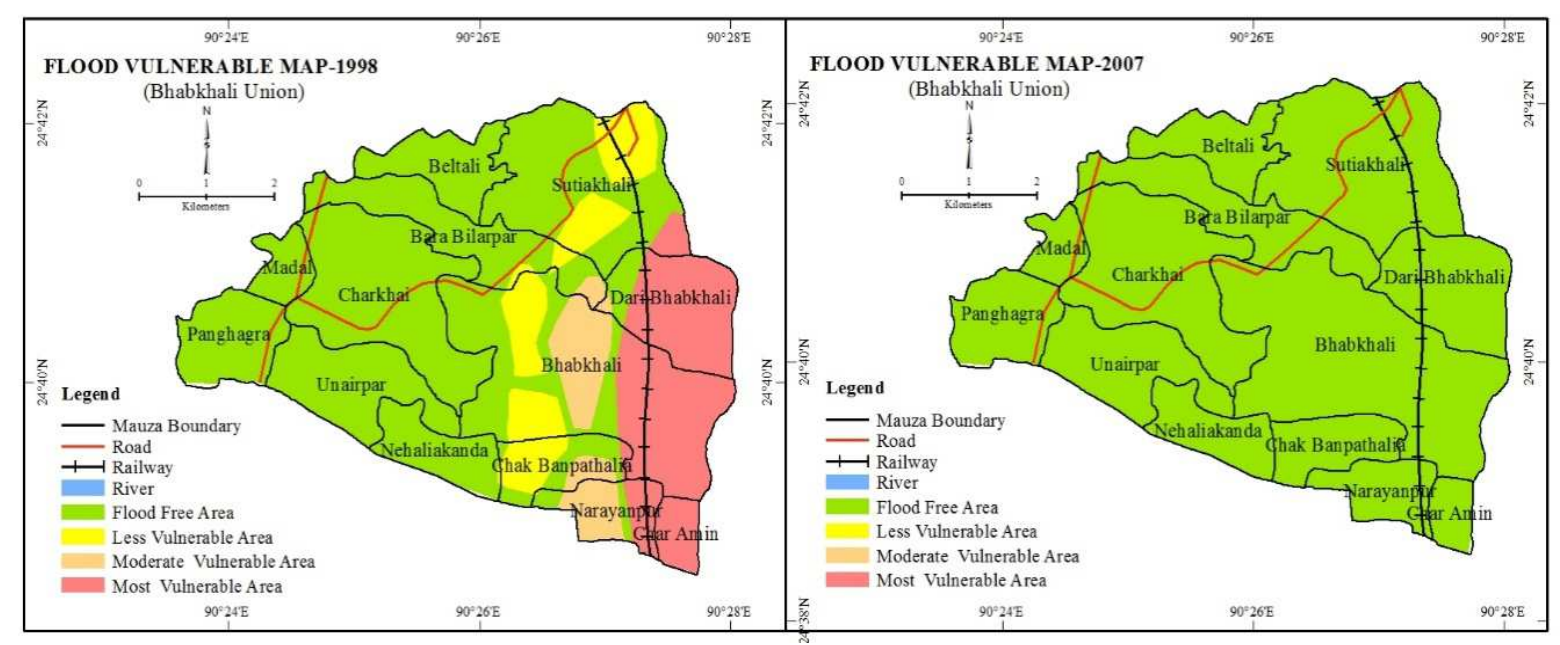

Fig. 18: Mouza base flood vulnerable map of Bhabkhali union, 1998 and 2007 Source: BCA\& LGED, analysis by Author, 2017 


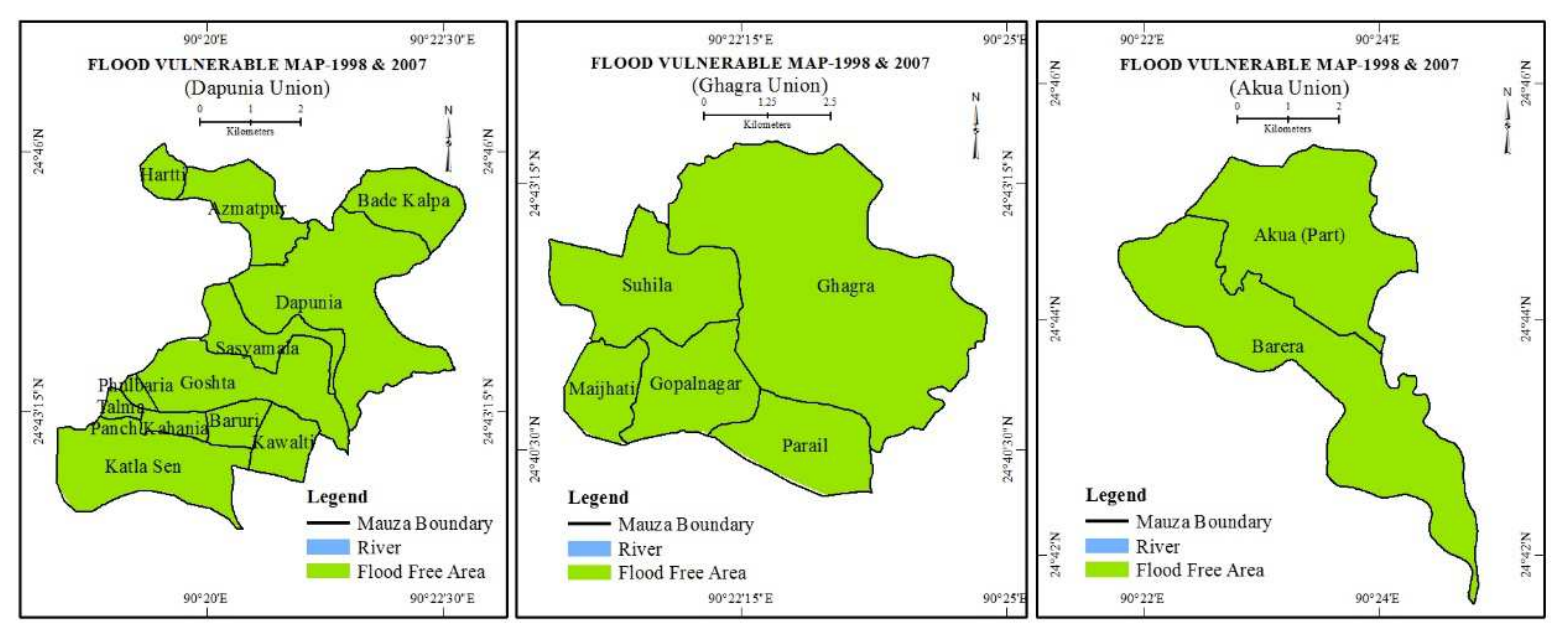

Fig. 19: Mouza base flood vulnerable map of Dapunia, Ghagra and Akua union, 1998 and 2007 Source: BCA \& LGED, analysis by Author, 2017

\section{Conclusion}

The frequent flood inundated the study area regularly. Completely flood vulnerable union are Borar Char, Paranganj, Sirta, Char Ishwardi and Char Nilakshmia. But flood vulnerable free union are Ghagra, Dapunia and Akua. Totally flood vulnerable free Mouza are Jagir Bhogli, Mirzapur, Maijbari, Ghanasampur, Kalikapur, Akua, Narayanpur, Chak Banpathalia, Nehaliakanda, Charkhai, Madal, Panghagra, Beltali. Many houses, primary schools, mosques, markets, agricultural land of Sadar Upazila of Mymensingh district are also under flood affected. Many infrastructures of this study area are also destroyed by the flood. Many important markets of this study area went into the water of the Old Brahmaputra River. Besides, many parts of the river bank eroded due to floods. Riverine flood is not a new phenomenon in our country. The flood may occur every year but people of our country should be adapted to this flood and government should take appropriate steps to reduce the flood vulnerability.

\section{Acknowledgement}

Authors greatly acknowledge to Mehedi Iqbal, Assistant Professor, Department of Geography and Environment, Jahangirnagar University for his valuable support on GIS mapping during the study. Thanks are due to Bangladesh Meteorological Department (BMD), Bangladesh Bureau of Statistics (BBS), Space Research and Remote Sensing Organization (SPARRSO), Flood Forecasting and Warning Center (FFWC) and Bangladesh Water Development Board (BWDB) for providing required data.

\section{Author's Contributions}

Muhammad Rezaul Rakib designed the research idea, analyzed the data, and wrote the manuscript; Md. Nurul Islam contributed in critical evaluation and interpretation of the manuscript. Muhammod Nazrul Islam finally revised the manuscript and provided significant intellectual content.

\section{Ethics}

Authors address no ethical issues that may arise after the publication of this manuscript.

\section{References}

Adnan, S., 1991. Floods: People And the Environment, Dhaka: Research and advisory services, Dhaka.

Alexander, D., 1989a. The case of Bangladesh. University of Massachussetts, Amherst, 15.

Alexander, D., 1989b. Consequences of floods in developing countries: International perspectives for disaster management. In the proceedings of the International Seminar on Bangladesh Floods: Regional and Global Environmental Perspectives, March 4-6, 1989, Bangladesh Research Bureau, Dhaka, P. 11.

Banglapedia, 2014. National Encyclopedia of Bangladesh, Asiatic Society of Bangladesh, Dhaka.

BWDB, 2010. Annual flood report, flood forecasting and warning centre. Bangladesh Water Devel. Board.

Bankoff, G., G. Frerks and D. Hilhorst, 2004. Mapping Vulnerability: Disasters, Development and People. 1st Edn., Earthscan, London, ISBN-10: 1849771928, pp: 256. 
Enhealth, 2002. Environmental Health Risk Assessment: Guidelines for assessing human health risks from environmental hazards. Department of Health and Ageing, Australia.

Geoscience, 2014. http://www.ga.gov.au/scientifictopics/hazards/risk-impact/vulnerability.

Hoyer, B.E., 1974. Flood Inundation Mapping and Remote Sensing in Iowa, Iowa Geologic Survey Publication Information Circular No. 6 (Iowa: Iowa Geologic Survey, 1974).

Jacobs, 2007. Strategic Flood Risk Assessment (SFRA). 1st Edn., London Borough of Hounslow, London.

Khalequzzaman, M., 1991a. Flood control megaproject in Bangladesh: Solution or Problem? Proceedings of the symposium Bangladesh and Natural Disasters Organized, Nov. 24-24, Canada-Bangladesh ForumOttawa, pp: 16.

Khalequzzaman, M., 1991b. Recent floods in Bangladesh: Possible causes and solutions. Perugia, Italy.

Khalequzzaman, M., 1992. Feasibility of the flood control megaproject in Bangladesh. Int. J. Environ. Educ. Information: 11: 19-24.

Khalequzzaman, M., 1994. Recent floods in bangladesh: Possible causes and solutions, University of Delaware Newark, DE 19716, USA, 9: 65-80.
Martinez-Graña, A.M., J.L. Goy, C. Zazo and M. Yenes, 2013. Engineering geology maps for planning and management of natural parks: Las Batuecas-Sierra de Francia and "Quilamas" (Central Spanish System, Salamanca, Spain). Geosciences, 3: 46-62.

Martínez-Graña, A.M., T. Boski, J.L. Goy, C. Zazo and C.J. Dabrio, 2016. Coastal-flood risk management in central Algarve: Vulnerability and flood risk indices (South Portugal). Ecological Indicators, 71: 302-316.

Prithvish, N. and S. Smita, 2007. Geographical information system concepts and business opportunities, concept publishing company, New Delhi.

Qader, M.M.M., 2003. Three recent extreme floods in Bangladesh: A Hydro-meteorological analysis. Springer, Natural Hazards, 28: 35-64.

Ramsbottom, D., P. Floyd and E. Penning-Rowsell, 2003. Defra/Environment Agency, Flood and Coastal Defense R\&D Programme. 1st Edn., Defra Flood Management Division, London.

Veleda, S., A.M. Martinez-Graña, F. Santos-Frances, J. Sanchez-San Roman and M. Criado, 2017. Analysis of the Hazard, vulnerability and exposure to the risk of flooding (Alba de Yeltes, Salamanca, Spain). Applied Sci., 7: 157-157. DOI: 10.3390/app7020157 